\section{Genetic engineering of cotton with a novel cry $2 A X 1$ gene to impart insect resistance against Helicoverpa armigera}

\section{Karunamurthy Dhivya ${ }^{1}$, Sundararajan Sathish ${ }^{1}$, Natarajan Ba- lakrishnan ${ }^{1}$, Varatharajalu Udayasuriyan ${ }^{1}$ and Duraialagaraja Sudhakar ${ }^{1 *}$}

\begin{abstract}
Embryogenic calli of cotton (Coker310) were cocultivated with the Agrobacterium tumefaciens strain LBA4404 harbouring the codon-optimised, chimeric cry2AX1 gene consisting of sequences from cry $2 A a$ and cry $2 A c$ genes isolated from Indian strains of Bacillus thuringiensis. Forty-eight putative transgenic plants were regenerated, and PCR analysis of these plants revealed the presence of the cry2AX1 gene in 40 plants. Southern blot hybridisation analysis of selected transgenic plants confirmed stable T-DNA integration in the genome of transformed plants. The level of Cry2AX1 protein expression in PCR positive plants ranged from 4.9 to $187.5 \mathrm{ng} \mathrm{g}^{-1}$ of fresh tissue. A transgenic cotton event, TP31, expressing the cry2AX1 gene showed insecticidal activity of 56.66 per cent mortality against Helicoverpa armigera in detached leaf disc bioassay. These results indicate that the chimeric cry $2 A X 1$ gene expressed in transgenic cotton has insecticidal activity against $H$. armigera.
\end{abstract}

Keywords: cry2AX1, Agrobacterium tumefaciens, somatic embryogenesis.

\section{INTRODUCTION}

Cotton is one of the most important crop species, valued around the world by the textile industry. Besides being the backbone of the textile industry, cotton and its by-products are also part of livestock feed, seed oil, fertilizers, paper, and other consumer products (Wilkins et al. 2000). Since cotton is highly susceptible to biotic and abiotic stresses, it requires intensive crop management. In cotton, bollworms, namely Helicoverpa armigera (Hubner), the American bollworm, Earias vittella (Fabricius), the spotted bollworm, and Pectinophora gossypiella (Saunders), the pink bollworm, pose serious threats to cotton production (Agarwal et al. 1984), causing yield loss of more than $50 \%$. Conventional plant breeding methods have been extensively applied to improve these traits. However, these approaches have been limited by the lack of sufficient genetic variability in the existing germplasm pool (Wu et al. 2004). The control of insect pests has been accomplished primarily through the application of chemical pesticides, which lead to severe environmental problems. Moreover, many insects have developed resistance to different chemical pesticides, resulting in inefficient insect control programs. Considering the problems related to the action of these insecticides on non-target/beneficial organisms, environment and human health, it has become necessary to find alternative methods of control, which can be a part
Crop Breeding and Applied Biotechnology 16: 205-212, 2016 Brazilian Society of Plant Breeding. Printed in Brazil http://dx.doi.org/10.1590/198470332016v16n3a31

70332016v16n3a31 


\section{K Dhivya et al.}

of Integrated Pest Management (IPM).

In this context, genetic engineering provides an enormous scope for widening the genetic diversity of crop plants through stable expression of foreign genes from divergent sources, including bacteria. Bacillus thuringiensis (Bt) is perhaps the most important source of insect resistance genes. Resistance to insects through deployment of Bt genes is one of the most successful strategies in modern agriculture. Genetically engineered (GE) crops were grown on 175.2 million hectares globally in 2013 (James 2013). Among them, transgenic cotton expressing insecticidal proteins from Bt has been one of the most rapidly adopted GE crops in the world (James 2012, Lu et al. 2012). Cultivation of Bt transgenic cotton has allowed a significant decrease in the use of chemical insecticides and, consequently, in environmental pollution and human exposure to toxins (Bennett et al. 2004). Bt toxins are also highly specific against insect pests, without affecting predators and other beneficial insects (Christou 2005). Due to these advantages, Bt cotton varieties or hybrids are recognized as a valuable component of an integrated pest management system.

Integration of genes encoding proteins from Bt has made it possible to obtain cotton lines that are resistant to several polyphagous insects (Perlak et al. 1990, Perlak et al. 1991). The ultimate goal is to obtain durable protection, which specifically requires stability of gene expression during the course of selfing or backcrossing, and also requires reducing the probability of development of resistant insects. Transgenic Bt cotton expressing cry $1 A c$ has been registered for commercial cultivation in India since 2002, and it primarily targets Helicoverpa armigera.

A major concern of using transgenics with a single Bt toxin is the possibility of breakdown of insect resistance in plants. However, Tabashnik et al. (2003) have shown that insects that developed resistance against Cry1A are still susceptible to the Cry2A protein. Therefore, pyramiding two or more Bt genes with different modes of action is one of the strategies to delay development of resistance in insects. The combination of $c r y 1 A c$ and $c r y 2 A b$ in the second version of Bt cotton (BGII) exhibited superior control of lepidopteran pests and delayed development of resistance in insects (Perlak et al. 2001). Commercial Bt crops expressing Cry1Ab, Cry1Ac, Cry1F, Cry2Ab, and Cry3Bb proteins, with different modes of action, either individually or in combination, are now being grown worldwide with protection against a variety of insect pests.

With a view toward developing an alternative gene belonging to the cry2 group, a novel chimeric cry2AX1 gene was constructed, consisting of sequences from cry2Aa and cry2Ac (Udayasuriyan et al. 2010). Due to differences in structural and insecticidal mechanisms, cry $2 A$ genes are potential candidates for management of resistance in insects when deployed in combination with cry1. In this study, the codon-optimised synthetic cry2AX1 gene was used in cotton transformation to develop cotton plants exhibiting insecticidal activity against $H$. armigera.

\section{MATERIAL AND METHODS}

\section{Plasmid constructs and binary vector}

The codon-optimised 1902 bp synthetic cry2AX1 gene (Acc. No. GQ332539.1) fused downstream of the cotton transit peptide sequence (186 bp) from the Ribulose bisphosphate carboxylase small subunit ( $r b c S 1 b)$ gene family (Acc. No. JN608790.1) was cloned under the control of a double enhancer version of CaMV35S promoter and nos termination signal in pCAMBIA 2300 backbone (Ruturaj et al. 2014). The Agrobacterium strain LBA4404 harbouring the above construct (p2300-tp2AX1) (Figure 1) was used for cotton transformation.

\section{Plant material}

Seeds of Gossypium hirsutum cv. Coker310 were surface sterilized and germinated in half-strength MS medium. Cotyledons and hypocotyls derived from one week old seedlings were used as explants for callus induction.

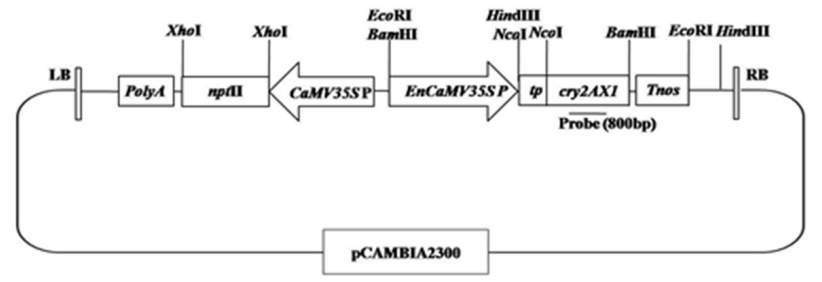

Figure 1. T-DNA region of plant transformation construct p2300$\operatorname{tp} 2 A X 1$. Cotton chloroplast transit peptide (tp) was fused to the cry $2 A X 1$ gene. The tp-cry $2 A X 1$ gene is driven by a double enhancer CaMV35S promoter and terminated by the nopaline synthase (nos) terminator. The plant selectable marker gene nptll is under the control of the duplicated CaMV35S promoter and tailed by the CaMV35S polyA. LB: left border of T-DNA region; $\mathrm{RB}$ : right border of T-DNA region. 


\section{Callus induction and somatic embryogenesis}

\section{Initiation and maintenance of embryogenic calli}

Cotyledonary (10-16 $\left.\mathrm{mm}^{2}\right)$ and hypocotyl (3-5 mm) segments were used as explants for callus induction. Calli were cultured on MS medium supplemented with $0.5 \mathrm{mgL}^{-1}$ kinetin and $0.1 \mathrm{mgL}^{-1}$ 2,4-D (2,4-Dichlorophenoxyacetic acid) (Trolinder and Goodin 1988a) and 3\% maltose. The proliferated calli were cultured on MS medium containing $1.9 \mathrm{gL}^{-1}$ $\mathrm{KNO}_{3}$ for initiation of somatic embryogenesis (Trolinder and Goodin 1988b) (Figure 2).

\section{Genetic transformation and plant regeneration}

Friable embryogenic calli were cultured with Agrobacterium strain LBA4404 (p2300-tp2AX1) (Leelavathi et al. 2004). After cocultivation, the calli were subcultured on MS medium supplemented with $1.9 \mathrm{gL}^{-1} \mathrm{KNO}_{3}, 25 \mathrm{mgL}^{-1}$ kanamycin, and $250 \mathrm{mgL}^{-1}$ cefotaxime until initiation and maturation of somatic embryos. The mature somatic embryos with true cotyledons were germinated on MS medium containing $0.1 \mathrm{mgL}^{-1} \mathrm{GA} 3$ (Giberellic acid), $1.0 \mathrm{mgL}^{-1}$ IAA(Indole-3-acetic acid), and $3 \%$ sucrose. The regenerated plantlets were transferred to soil (soil:sand:peat mixture 1:1:1) for hardening (Figure 2).

\section{Molecular analysis of putative transgenic plants}

Genomic DNA was isolated from the leaves of putative transgenic and non-transgenic control plants (Stewart and Via 1993). PCR analysis was performed to analyse the presence of cry2AX1 and nptII (Neomycin phosphotransferase) genes in the putative transgenic lines of Coker 310 using gene specific primers, cry2AX1: FP 5'-AACGTTCTTAACTCTGGAAGGA-3'; RP 5'-GCAGAAATTCCCCACTCATCAG-3' and nptII:FP 5'-CTGATGCTCTTCGTCCAGAT-3'; RP 5'AGAGGCTATTCGGCTATGACT-3'. The presence of the actin gene was checked as an internal control.

Southern blot hybridisation analysis was done to confirm the integration of the transgene in putative $T_{0}$ transgenic plants. For Southern blot hybridisation analysis, $10 \mu \mathrm{g}$ of genomic DNA was digested with $E C O R I$, which releases the cry2AX1 gene ( $3.1 \mathrm{~kb}$ size). The digested products were gel electrophoresed on $0.8 \%$ agarose gel and blotted onto a positively charged nylon membrane. For hybridisation, the 800 bp internal region of the cry2AX1 gene was used as a probe. The probe DNA was radio-labelled with $\alpha^{32}-P$ dCTP (Deoxycytidine triphosphate) by random priming using the Decalabel DNA labelling kit (Thermo Scientific Inc.). The blot was washed with $3 X$ SSC (Saline-sodium citrate) $+0.1 \%$ SDS (Sodium dodecyl sulphate) and $2 X$ SSC $+0.1 \%$ SDS for 15 min each, followed by $10 \mathrm{~min}$ in $0.5 \mathrm{X}$ $\mathrm{SSC}+0.1 \% \mathrm{SDS}$ at $60^{\circ} \mathrm{C}$ after hybridisation. The membrane was exposed to X-ray film for a week.

\section{Estimation of Cry2AX1 protein by ELISA}
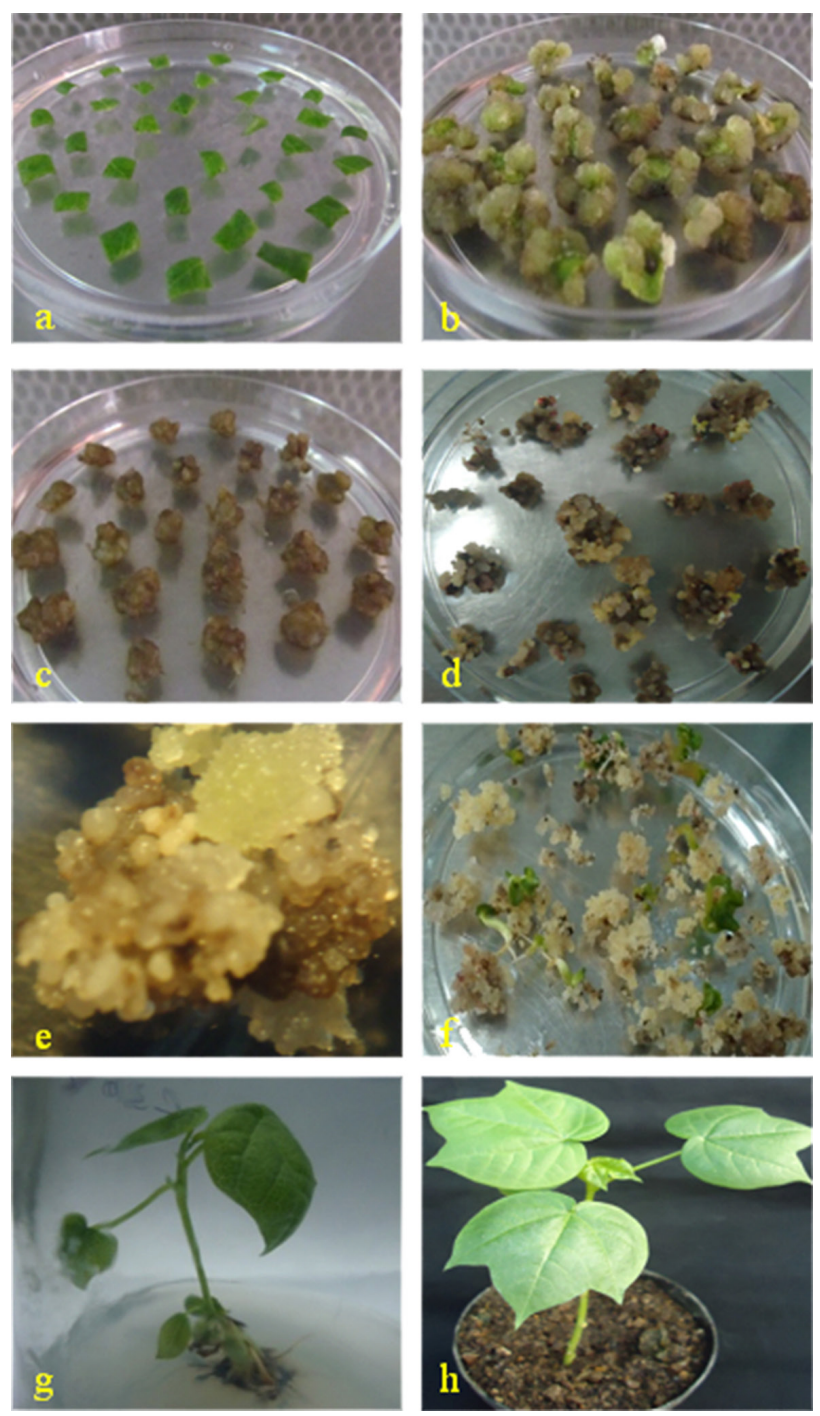

Figure 2. Agrobacterium-mediated transformation of cotton. a. Cotyledon explant inoculation (Explant from 7 day old seedlings). b. Callus induction on cotyledon explants (30 days). c. Pre-embryogenic calli for cocultivation (180 day old calli). d. Proliferation of embryogenic calli (30-45 days). e. Proliferated somatic embryos (45-60 days). f. Friable embryogenic cultures with cotyledonary embryos (30 days). g. Regeneration of complete plant (30-45 days). h. Plant with well-developed roots after transfer to soil (15-20 days). 
The Cry2AX1 protein levels in the putative transgenic plants were analysed using the Enzyme Linked Immunosorbent Assay quantitative (ELISA) kit (Envirologix, USA) as per manufacturer's instructions. Protein extracts were made by grinding $30 \mathrm{mg}$ of leaf tissues (fully expanded terminal leaf) in $500 \mathrm{~mL}$ of extraction buffer (provided in the kit) and centrifuged at $10,000 \mathrm{rpm}$ for $10 \mathrm{~min}$ at $4{ }^{\circ} \mathrm{C}$. An aliquot of $100 \mu \mathrm{L}$ of leaf extracts was loaded into the ELISA plate. Colour intensity was observed at $450 \mathrm{~nm}$. Proper negative and positive controls (standards provided in the kit) were included in the experiment. The Cry2AX1 protoxin was quantified based on standards provided with the kit.

\section{Detached leaf disc insect bioassay}

Putative $T_{0}$ transgenic plants were subjected to insect bioassay to assess insecticidal activity of the Cry2AX1 protein against cotton bollworm, $H$. armigera. Leaf discs $(3 \mathrm{~cm}$ diameter) of putative transgenic $\left(\mathrm{T}_{0}\right)$ and non-transformed (control) plants were placed on a wet filter paper placed inside a sterile petriplate. Ten first instar larvae of $H$. armigera were released per replication. Three replications were maintained in each line, and the bioassay was carried out at $26-28^{\circ} \mathrm{C}$ with $60 \%$ relative humidity. Larval mortality and larval growth were recorded for five days.

\section{Statistical analysis}

The experimental data values of Cry2AX1 protein concentration and mortality of $H$. armigera were mean values from three replicates, and the results were presented as mean \pm SD. All mortality data were subjected to arcsine transformations before analysis. Data analysis was done by analysis of variance (ANOVA) following the AGRES statistical package. Mean values were separated by Duncan's multiple range test (DMRT) at a 5 per cent probability level (Duncan 1955).

\section{RESULTS AND DISCUSSION}

\section{Generation and evaluation of transgenic plants}

The cultivation of transgenic cotton ( $G$. hirsutum L.) rapidly gained a great deal of ground in the late 1990s and now accounts for most cotton production in the US and many other countries, including India. The transformation and regeneration of cotton via somatic embryogenesis is a long process, and cotton remains one of the recalcitrant species to be manipulated in culture (Wilkins et al. 2000). Somatic embryogenesis in cotton is hampered by its extended culture period, low frequency of embryos, and high incidence of abnormal embryos (Kumria et al. 2003). Low conversion rates of somatic embryos into complete plantlets in cotton

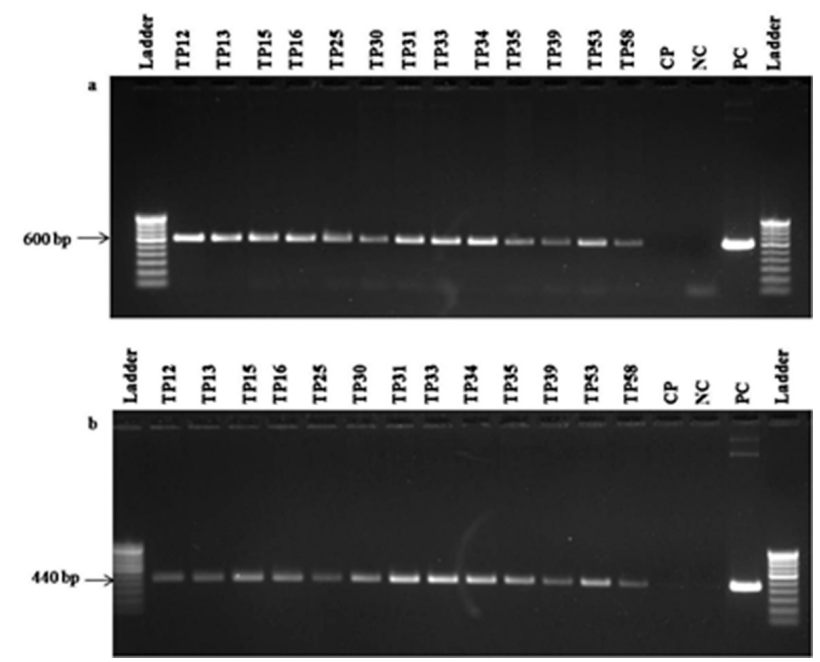

Figure 3. PCR analysis of cry $2 A X 1$ transgenic cotton plants. a. A $600 \mathrm{bp}$ internal sequence of the cry2AX1 gene amplified by PCR from the DNA isolated from putative transgenic plants. $b$. A 440 bp internal sequence of the nptll gene amplified by PCR from the DNA isolated from putative transgenic plants. Ladder: 100 bp ladder, Lane 2-14: Putative cotton transgenic plants, CP: non-transformed plant, NC: negative control, PC: positive control (p2300-tp2AX1 plasmid).

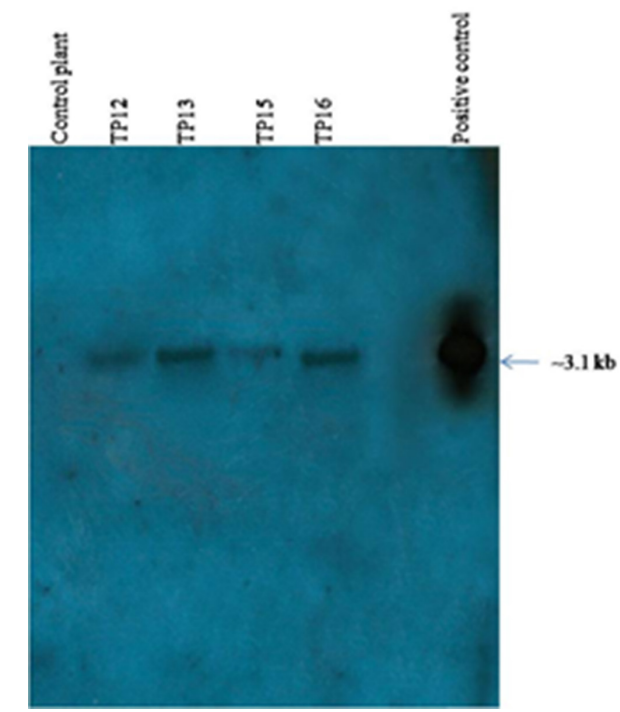

Figure 4. Southern blot analysis of putative $T$ transgenic plants. DNA digested with EcoRI and probed with a radioactively labelled $800 \mathrm{bp}$ internal sequence of the cry2AX1 gene. Lane 1: Control plant, Lane 2: TP12, Lane 3: TP13, Lane 4: TP15, Lane 5: TP16, Lane 6: blank, Lane 7: positive control (p2300-tp2AX1plasmid). 
tissue culture have been reported (Voo et al. 1991, Zhang et al. 1993). In germinating somatic embryos, rooting is an inefficient process and one that has received scant attention. In the Coker genotypes, only $\sim 5-6 \%$ of somatic embryos root sufficiently to allow recovery of complete plants (Wilkins et al. 2000).

We introduced a synthetic cry2AX1 gene into cotton plants (Coker310) through Agrobacterium mediated transformation to evaluate its efficacy against cotton bollworm, H. armigera. Six month old friable embryogenic calli that were cocultivated with the Agrobacterium strain LBA4404 (p2300-tp2AX1) construct proliferated into somatic embryos, whereas no proliferation was observed in non-transformed calli. Transformation of cotton with the synthetic cry2AX1 gene (consisting of sequences of cry $2 A a$ and $c r y 2 A c$ genes) resulted in generation of 48 putative transgenic plants.

In PCR analysis carried out with gene specific primers to confirm the presence of transgenes in putative transgenic plants, 40 plants were found to possess cry2AX1 and nptllgenes (Figure 3a, b). No amplification was observed in nontransformed control plants. Southern blot hybridisation analysis of cry2AX1 transformants indicated stable integration of the cry $2 A X 1$ gene in the genome of transgenic cotton plants, whereas the untransformed control plant did not show any sign of hybridisation (Figure 4).

The selected PCR positive transgenic plants were subjected to ELISA for quantification of the insecticidal Cry2AX1 protein. Thirteen out of 40 PCR positive plants were found to be positive for expression of the Cry2AX1 protein. However, we observed a wide variation of expression in the transgenic lines developed, ranging from 4.9 to $187.5 \mathrm{ng} \mathrm{g}^{-1}$ of fresh leaf tissue (Table 1). A wide range of Bt protein expression in transgenic plants with the same genetic background and gene construct were reported by several earlier studies (Maqbool et al. 2001, Breitler et al. 2000, Ramesh et al. 2004,

Table 1. Bioassay on putative $\mathrm{T}_{0}$ transgenic cotton lines against Helicoverpa armigera

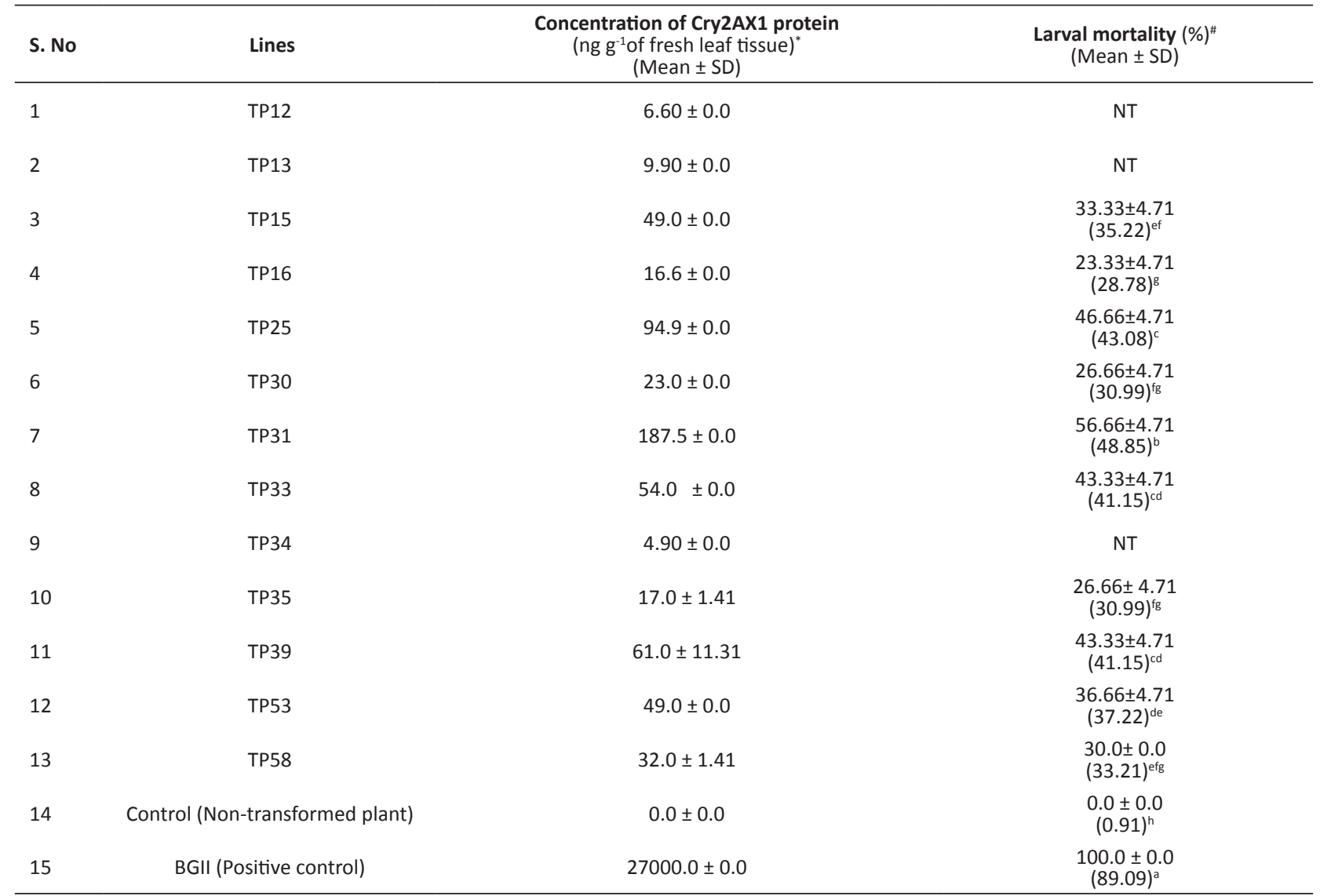

" Mean of two replicates; " Mean of three replicates; NT - Not tested; Figures in parentheses are arcsine transformed values; Standard Error of Deviation SEd = 2.50; Critical Difference $C D(0.05)=5.16$; Coefficient of Variation CV\% = 7.98; Means followed by the same small letters within a column are not significantly different at the $5 \%$ level in Duncan's multiple range test (DMRT) 
Meiyalaghan et al. 2006). We reason that the variation in the level of transgene expression or lack of expression may be due to mutations in the transgene, truncation of T-DNA during integration, post transcriptional gene silencing, or transcriptional gene silencing (integration of T-DNA into genomic regions such as the heterochromatin that repress transgene expression) (Francis and Spiker 2005). Inactivation of the transgene is often shown to be accompanied by an increase in DNA methylation (Amasino et al. 1984). Inactivation also very frequently correlates with the number of copies of integrated transgenes (Jones et al. 1987).

\section{Insect bioassay of cry2AX1 transgenic cotton plants}

Laboratory biotoxicity assays with the first instar $H$. armigera larvae were conducted to analyse the efficacy of Cry2AX1 protein in cotton transformants. The results of leaf disc bioassay studies showed larval mortality ranging from 23.33 to $56.66 \%$ in the selected ELISA positive plants (Table 1). The surviving larvae on transgenic plants showed severe growth inhibition and significant reduction in leaf feeding, whereas larvae released on control plants were alive with normal growth (Figure 5). Earlier reports suggest that the protein concentration is directly related to the level of insect resistance in Bt transgenic plants (Chen et al. 2005, Rashid et al. 2008, Mehrotra et al. 2011). Differences in the level of toxicity (mortality) observed among the different transgenic lines could be attributed to differences in the level of Bt gene expression. Variation of a single amino acid can also significantly influence the level of toxicity in Cry proteins (Udayasuriyan et al. 1994, Rajamohan et al. 1996). a
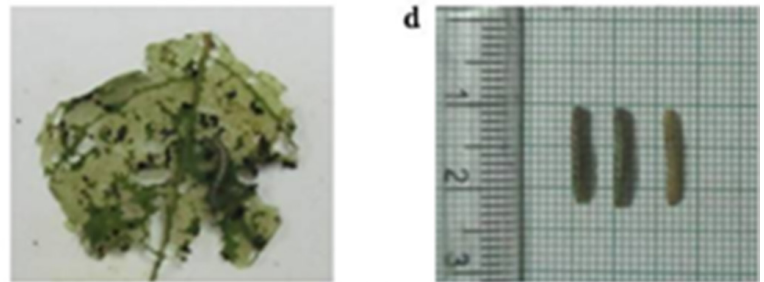

Non transformed control

b

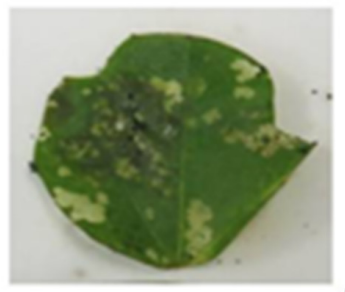

c

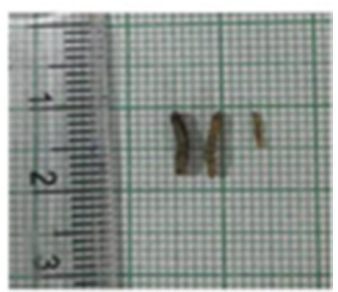

TP31

c

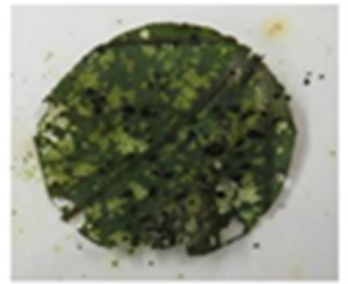

f

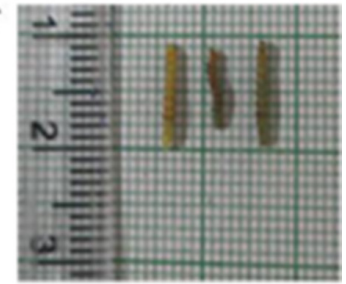

TP25

Figure 5. Detached leaf disc bioassay against cotton boll worm (Helicoverpa armigera) in transgenic cotton plants expressing the Cry2AX1 protein. a. Non-transformed control (Coker310), b. Transformed cotton plant TP31, c. Transformed cotton plant TP25; d, e, f. Surviving larvae on control and transformed plants.

The Cry2Aa protein is known to be toxic to prominent lepidopteran insect pests like rice stem borers and brinjal fruit and shoot borer (Maqbool et al. 1998, Rao et al. 1999). Pesticidal activity of $B$. thuringiensis $\delta$-endotoxins, Cry1Aa, Cry1Ab, Cry1Ac, and Cry2A against Helicoverpa zea was determined by Karim et al. (2000). H. zea was susceptible to Bt toxins in the order Cry1Ac, Cry1Ab, Cry1Aa, and Cry2A with 63.60, 89.04, 159.65, and 375.78 ng/larvae, respectively. Indian populations of $H$. armigera were 5- to 30-fold less susceptible to cry2Aa than cry1Ac (Chakrabarti et al. 1998, Babu et al. 2002, Misra et al. 2002). The expression level of Cry2Ab in commercialized Bt cotton ranges from 16.8 to 22.7 $\mu \mathrm{g} \mathrm{g}^{-1}$ in fresh leaf tissue (Li et al. 2011). These findings indicated that a greater amount of Cry2AX1 protein expression may be needed to achieve the desirable level of insecticidal activity in plants.

In the current investigation, an attempt was made to study the insecticidal activity of the cry2AX1 gene against $H$. armigera in cotton. The $H$. armigera neonates showed mortality up to $56.66 \%$ in the transgenic plants, even with a relatively lower level of Cry2AX1 protein in the plant (about $187.5 \mathrm{ng} \mathrm{g}^{-1}$ of leaf tissue). The expression of a higher level of Cry2AX1 protein and high insecticidal activity can possibly be achieved by generating or screening more transgenic plants. A transgenic plant carrying the $c r y 2 A X 1$ gene with higher insecticidal activity could be an alternative management strategy for $\mathrm{H}$. armigera in cotton.

\section{ACKNOWLEDGEMENTS}

The authors express their gratitude to the Council of Scientific and Industrial Research (CSIR), Government of India, New Delhi, for financial assistance in the form of a network project (CSIR Order No. 5/258/53/2006- NMITLI dt. 18.3.2008). 
We thank Prof. D. Pental and Prof. P.K. Burma, University of Delhi South Campus, Delhi for providing the rbcs1b cotton transit peptide sequence. We also thank Dr. P. Nandeesha (currently working in Indian Institute of Horticultural Research, Bengaluru) for making the construct.

\section{REFERENCES}

Agarwal RA, Gupta GP and Grag DO (1984) Cotton pest management in India. Research Publication, Azad Nagar, Delhi, p. 1-191.

Amasino RM, Powell ALT and Gordon MP (1984) Changes in T-DNA methylation and expression are associated with phenotypic variation and plant regeneration in a crown gall tumor line. Molecular and General Genetics 197: 437-446.

Babu BG, Udayasuriyan V, Mariam MA, Sivakumar NC, Bharathi M and Balasubramanian G (2002) Comparative toxicity of Cry1Ac and Cry2Aa $\delta$-endotoxins of Bacillus thuringiensis against Helicoverpa armigera (H.) Crop Protection 21: 817-822.

Bennett RM, Ismael Y, Kambhampati V and Morse S (2004) Economic impact of genetically modified cotton in India. AgBioForum 7: 96-100.

Breitler JC, Marfa V, Royer M, Meynard D, Vassal JM, Vercambre B, Frutos R, Messeguer J, Gabarra R and Guiderdoni E (2000) Expression of a Bacillus thuringiensiscry1B synthetic gene protects Mediterranean rice against the striped stem borer. Plant Cell Reports 19: 1195-1202.

Chakrabarti SK, Mandaokar AJ, Kumar PA and Sharma RP (1998) Toxicity of lepidopteran specific delta endotoxins of Bacillus thuringiensis towards neonate larvae of Helicoverpa armigera. Journal of Invertebrate Pathology 72: 336-337.

Chen H, Tang W, Xu C, Li X, Lin Y and Zhang Q (2005) Transgenic indica rice plants harbouring a synthetic cry2A gene of Bacillus thuringiensis exhibit enhanced resistance against lepidopteran rice pests. Theoretical and Applied Genetics 111: 1330-1337.

Christou P (2005) Sustainable and durable insect pest resistance in transgenic crops. ISB News Report. $3 p$.

Duncan DB (1955) Multiple range and multiple $F$ test. Biometrics 11: 1-42.

Francis KE and Spiker S (2005) Identification of Arabidopsis thaliana transformants without selection reveals a high occurrence of silenced T-DNA integrations. The Plant Journal 41: 464-477.

James C (2012) Global review of commercialized transgenic crops: 2012 feature: Bt cotton. ISAAA Briefs No. 44. ISAAA, Ithaca, 329p.

James C (2013) Global review of commercialized transgenic crops: 2013 feature: Bt cotton. ISAAA Briefs No. 46. ISAAA, Ithaca, 332p.

Jones JDG, Gilbert DE, Grady KL and Jorgensen RA (1987) T-DNA structure and gene expression in petunia plants by Agrobacterium tumefaciens C58 derivatives. Molecular and General Genetics 207: 478-485.

Karim S, Gould F and Dean DH (2000) Bacillus thuringiensis endotoxin proteins show a correlation in toxicity and short circuit current inhibition against Helicoverpa zea. Current Microbiology 41: 214-219.

Kumria R, Sunnichan VG, Das DK, Gupta SK, Reddy VS, Bhatnagar RK and Leelavathi S (2003) High-frequency somatic embryo production and maturation into normal plants in cotton (Gossypium hirsutum) through metabolic stress. Plant Cell Reports 21: 635-639.

Leelavathi S, Sunnichan VG, Kumria R, Vijaykanth GP, Bhatnagar RK and Reddy VS (2004) A simple and rapid Agrobacterium-mediated transformation protocol for cotton (Gossypium hirsutum L.): embryogenic calli as a source to generate large numbers of transgenic plants. Plant Cell Reports 22: 465-470.

Li Y, Romeis J, Wang P, Peng Y and Shelton AM (2011) A comprehensive assessment of the effects of Bt cotton on Coleomegilla maculata demonstrates no detrimental effects by Cry1Ac and Cry2Ab. PLoS One 6(7): e22185.

Lu Y, Wu K, Jiang Y, Guo Y and Desneux N (2012) Widespread adoption of Bt cotton and insecticide decrease promotes biocontrol services. Nature 487: 362-365.

Maqbool SB, Husnain T, Raizuddin S and Christou P (1998) Effective control of yellow rice stem borer and rice leaf folder in transgenic rice Indica varieties Basmati 370 and $\mathrm{M} 7$ using novel $\delta$-endotoxin cry2A Bacillus thuringiensis gene. Molecular Breeding 4: 501-507.

Maqbool SB, Raizuddin S, Loc TN, Gatehouse AMR, Gatehouse JA and Christou P (2001) Expression of multiple insecticidal genes confers broad resistance against a range of different rice pests. Molecular Breeding 7: 85-93.

Mehrotra M, Sanyal I and Amla DV (2011) High efficiency Agrobacteriummediated transformation of chickpea (Cicer arietinum L.) and regeneration of insect- resistant transgenic plants. Plant Cell Reports 30: $1603-1616$

Meiyalaghan S, Jacobs JME, Butler RC, Wratten SD and Conner AJ (2006) Transgenic potato lines expressing cry1ba1or cry1ca5 genes are resistant to potato tuber moth. Potato Research 49: 203-216.

Misra HS, Khairnar NJP, Mathur M, Vijiyalakshmi N, Hire RS, Dongre TK and Mhanan SK (2002) Cloning and characterization of an insecticidal crystal protein gene from Bacillus thuringiensis subspecies kenyae. Journal of Genetics 81: 5-11.

Perlak FJ, Deaton RW, Armstrong TA, Fuchs RL, Sims SR, Greenplate JT and Fischoff DA (1990) Insect resistant cotton plants. Nature Biotechnology 8: 939-943.

Perlak FJ, Fuchs RL, Dean DA, McPherson SL and Fischhnff DA (1991) Modification of the coding sequence enhances plant expression of insect control protein genes. Proceedings of the National Academy of Sciences 88: 3324-3328.

Perlak FJ, Oppenhuizen M, Gustafson K, Voth R, Sivasubramanian S, Heering D, Carey B, Ihrig RA and Roberts JK (2001) Development and commercial use of Bollgard ${ }^{\circ}$ cotton in the USA early promises versus today's reality. The Plant Journal 27: 489-501. 


\section{K Dhivya et al.}

Rajamohan F, Alzate O, Cotrill JA, Curtiss A and Dean DH (1996) Protein engineering of Bacillus thuringiensis $\delta$ endotoxin: Mutations at domain II of Cry1Ab enhance receptor affinity and toxicity towards gypsy moth larvae. Proceedings of the National Academy of Sciences 93: $14338-14343$.

Ramesh S, Nagadhara D, Pasalul C, Kumari AP, Sarma NP, Reddy VD and Rao KV (2004) Development of stemborer resistant transgenic parental lines involved in the production of hybrid rice. Journal of Biotechnology 111: 131-141

Rao NGV, Majumdar A, Mandaokar AD, Nimbalkar SA and Kumar PA (1999) Susceptibility of brinjal shoot and fruit borer to the d-endotoxins of Bacillus thuringiensis. Current Science 77: 336-337.

Rashid B, Zafar S, Husnain T and Riazuddin S (2008) Transformation and inheritance of Bt genes in Gossypium hirsutum. Journal of Plant Biology 51: 248254.

Ruturaj RB, Naveenkumar A, Nandeesha P, Manikandan R, Balakrishnan N, Balasubramani V, Sudhakar D and Udayasuriyan V (2014) Transformation of tomato with cry2AX1 gene of Bacillus thuringiensis. International Journal of Tropical Agriculture 32: 577-585.

Stewart CN and Via LE (1993) A Rapid CTAB DNA isolation technique useful for RAPD fingerprinting and other PCR Applications.BioTechniques 14: 748-749.

Tabashnik BE, Carriere Y, Dennehy TJ, Morin S, Sisterson MS, Roush RT, Shelton AM and Zhao JZ (2003) Insect resistance to transgenic Bt crops: lessons from the laboratory and field. Journal of Economic Entomology 96: 1031-1038.
Trolinder NL and Goodin JR (1988a) Somatic embryogenesis in cotton (Gossypium). I. Effects of source of explant and hormone regime. Plant Cell, Tissue and Organ Culture 12: 178-181.

Trolinder NL and Goodin JR (1988b) Somatic embryogenesis in cotton (Gossypium). II. Requirements for embryo development and plant regeneration. Plant Cell, Tissue and Organ Culture 12: 43-53.

Udayasuriyan V, Indra Arulselvi P, Balasubramani V, Sudha DR, Balasubramanian P and Sangeetha P (2010) Construction of new chimeric cry2AX1 gene of Bacillus thuringiensis encoding protein with enhanced insecticidal activity. (Indian patent number 244427).

Udayasuriyan V, Nakamura A, Mori A, Masaki H and Uozumi T (1994) Cloning of a new $\operatorname{crylA}(a)$ gene from $B$. thuringiensis strain FU-2-7 and analysis of chimeric Cry $1 \mathrm{~A}(\mathrm{a})$ proteins of toxicity. Bioscience, Biotechnology, and Biochemistry 58: 830-835.

Voo KS, Rugh CL and Kamalay JC (1991) Indirect somatic embryogenesis and plant recovery from cotton (Gossypium hirsutum L.). In Vitro Cellular \& Developmental Biology - Plant 27: 117-124.

Wilkins T, Rajasekaran K and Anderson DM (2000) Cotton biotechnology. Critical Reviews in Plant Sciences 19: 511-550.

Wu JH, Zhang XL, Nie YC, Jin SX and Liang SG (2004) Factors affecting somatic embryogenesis and plant regeneration from a range of recalcitrant genotypes of Chinese cottons (Gossypium hirsutum L.) In Vitro Cellular \& Developmental Biology - Plant 40: 371-375.

Zhang BH, Li XL, Li FL and Li FG (1993) Plant recovery from cotton somatic embryos. Acta Agricultural Boreali-occidentalis Sinica 2: 24-28. 